\title{
Determinants of Long-Acting and Permanent Methods (LAPMS) of contraception use in Jambi Province, Indonesia
}

\author{
Hardiani Hardiani $^{1 *}$; Dwi Hastuti²; Islakhiyah Islakhiyah ${ }^{3}$; Junaidi Junaidi ${ }^{4}$ \\ 1), 2), 4) Economics Department, Faculty of Economics and Business, Universitas Jambi, \\ Indonesia \\ ${ }^{3)}$ National Population and Family Planning Board (BKKBN), Jambi Province, \\ Indonesia
}

*To whom correspondence should be addressed.Email: hardiani@unja.ac.id

\begin{tabular}{|l|l|l|l|l|}
\hline DOI: & Received: & Revised: & Accepted: & Published: \\
10.22437/ppd.v8i4.10701 & 15.09 .2020 & 01.11 .2020 & 02.11 .2020 & 07.11 .2020 \\
\hline
\end{tabular}

\begin{abstract}
The use of long-acting and permanent methods of contraception (LAPMs) by couples of reproductive age in Jambi Province is still comparatively low. Long-term contraception users were only 18.26 percent in 2018. Based on these, the objective of the study is to analyze as follows: 1) the determinants of LAPMs and non-LAPMs used by couples of reproductive age; 2) the relationship between couples of reproductive age and use of LAPMs. Data is obtained from the 2018 Performance Monitoring and Accountability of Population, Family Planning, and Family Development programs. Data were analyzed using binary logistic regression, One-way ANOVA and Chi-Square Test. The results of the analysis found that the determinants of LAPM and non-LAPM selection by couples of reproductive age are woman's educational attainment, woman's employment status, the difference between ideal and actual number of surviving children, the desire for more children, the knowledge of contraceptive methods, economic conditions, and urban-rural residence. Furthermore, the characteristics of couples of reproductive age significantly related to the LAPM choice include woman's age, woman's educational attainment, the actual number of surviving children, the difference between ideal and actual number of surviving children, the desire for more children, the knowledge of contraceptive methods, economic conditions, and urban-rural residence.
\end{abstract}

Keywords: Couples of reproductive age, Long-Acting and Permanent Methods, Program Performance and Accountability Survey

JEL Classification: J12, J13

\section{INTRODUCTION}

A high rate of population growth will bring new burdens and problems to development. High population growth that is not accompanied by an improvement in human quality will hamper efforts to enhance welfare in various aspects of life. Consequently, controlling population is the priority that must be done in order to ensure the accomplishment of development goals and development sustainability.

Jambi Province is one of the regions with high population growth rate in Indonesia. In the period $2000-2015$, the population growth of Jambi Province reached 2.71 percent 
per year and was higher than the national average of 1.58 percent per year.

There are three components of population growth: fertility, mortality, and migration. Fertility is the most decisive and possible component to be implemented in the context of policies and efforts to slow down population growth in the region (Hardiani \& Junaidi, 2018).

Family Planning (FP) programs, officially known as Population, Family Planning, and Family Development Programs (Program Kependudukan Keluarga Berencana dan Pembangunan Keluarga/PKKBPK), coordinated by a government institution, called National Population and Family Planning Board (Badan Kependudukan dan Keluarga Berencana Nasional/BKKBN), are potential solutions to control population growth (Septalia \& Puspitasari, 2016)

One of FP programs is using contraception to prevent unwanted pregnancies (Goldsmith et al. 2008), as well as to minimize maternal mortality and maternal morbidity associated with unintended pregnancy, to reduce the risk of infant mortality, to reduce the number of abortions, and to prevent HIV (Tsui et al., 2010; Glasier \& Gebbie, 2016; Peipert et al., 2012; Mehra et al., 2012; Cleland et al., 2012; Espey \& Ogburn, 2011) Delaying the first birth of young women is expected to increase the opportunities for education, training, and employment with increased productivity (Benagiano et al., 2007).

Based on its period of effectiveness, contraceptive methods are divided into two types. First, LAPMs (long-acting and permanent methods) or long-term methods of contraception are contraceptives that can last three years to lifetime, including IUD, implants, female sterilization (FS), and male sterilization (MS). Second, non-LAPMs include condoms, pills, injections, and other methods other than LAPMs.

One of the determinants of the decreased total fertility rate is the use of contraception for a long period. It can be realized if couples of reproductive age use longterm contraception, namely IUD, implants, FS, and MS. At the national level, the number of modern method users did not meet the target for the 2014-2019 BKKBN Strategic Planning. It was 57.20 percent in 2017 (BKKBN, BPS, Kemenkes \& ICF, 2018) which was below the targeted number of 61.30 percent in the BKKBN Strategic Planning (2019). The same is true of LAPMs, which was just 13.3 percent in 2017. The low percentage of LAPM use is due to higher costs (Septalia \& Puspitasari, 2016)

Achievement rate of modern methods of contraception in Jambi Province is relatively good and the figure is above the national average rate. In 2017, the proportion of modern method users in Jambi Province was 63.5 percent, while at the national level there were 57.4 percent of modern method users. Nonetheless, the number of LAPM users in Jambi Province has not yet met the goal. LAPM users in Jambi Province were just 11.7 percent in 2017. This was not only below the national average but also far below the 2014-2019 BKKBN Strategic Planning of 23.5 percent in 2019 (BKKBN, BPS, Kemenkes \& ICF, 2018)

As there is a high fertility rate in couples of reproductive age and low use of longterm contraceptive methods (LAPMs) in Jambi Province, it is important to study the profile and determinants of LAPM users in Jambi Province in the context of the formulation of appropriate policies to increase the use of LAPMs and decrease the birth rate.

The contraceptive selection determinants in this study are based on Green (1980) and Health Belief Model Theory (1950) developed by Godfrey Hochbaum and Irwin Rosenstock. Green Theory states that the determinants influencing an individual to take action are influenced by two factors: behavior causes and non-behavior causes. Furthermore, according to studies by Septalia \& Puspitasari (2016) and Secura et al. 
(2010), the significant factor influencing the contraceptive selection is non-material cost in terms of experience, cultural barriers, mental barriers and accessibility barriers. According to Secura et al. (2010), long-term contraception is the first choice if there is no cost barrier.

Referring to the two theories, Notoatmodjo (2014) suggested that there are several factors related to the use of LAPMs, namely the predisposing factors that facilitate and underlie certain behaviors. These factors include knowledge, attitudes, beliefs, and values. This also includes age, educational level, employment, and the number of surviving children. Enabling factors are variables that enable or facilitate behaviors or action. These factors include facilities and infrastructure for encouraging health behaviors, such as Community Health Centers (Pusat kesehatan masyarakat/Puskesmas), Integrated Services Posts (Pos Pelayanan Terpadu/Posyandu), hospitals, availability of medicines, availability of contraceptive devices, etc. Reinforcing factors are factors that encourage or reinforce behavior. Sometimes, someone does not have a healthy behavior even though he/she knows and is able to have it. These factors include the support of the husband, friends' influence, and the role of health workers. In this sense, the attitude of a person can determine his or her actions and behavior.

In their research in North Africa, Duze \& Mohammed (2006) found that there are main factors related to contraceptive use, namely the level of welfare, the level of parity, the level of education, knowledge of contraceptive methods, and perceptions of birth control. Widyastuti \& Mahmudah (2012) found, in their research in Tawangmangu, that knowledge, parity, age, decision-making, selection reasons, educational attainment, employment, and income are determinants of contraceptive selection.

Herlinawati, et al. (2013) in their research in Medan found that parity, attitudes, and family support had an impact on woman's decision to choose FS as their method of contraception. Family/husband support is particularly noticeable in the research conducted by Ningrum, et al. (2017). Meanwhile, Hartanto (2004) has shown that the use of injections can be influence by a number of factors, including age, educational attainment, employment, income, support from husband, and knowledge.

In addition, Aldriana (2013) found that the factors determining the use of IUD are support from husband, the actual number of surviving children, mothers' knowledge of IUD, and the attitude of FP officers. Similar results have also been found by Budiarti, et al. (2017). They reported that there is a significant correlation between age, occupation/ employment, and support from husband or partner, and the use of long-term contraceptive methods by FP acceptors. Sudarti \& Kurniawidjaya (2013) have identified a significant relationship between educational attainment, occupation, the actual number of surviving children, knowledge, support from husband, and distance to the place of service, and the use of LAPMs. Rizani (2019) found that the use of long-term contraception is significantly affected by age, the number of surviving children, knowledge, attitudes, side effects, health status, and costs.

Research conducted by Dewi \& Notobroto (2014) identified three factors significantly influencing the use of long-term contraceptive, namely maternal age, the number of surviving children, and mothers' knowledge of contraceptive methods. The influence of maternal age on the use of LAPMs was also indicated in the research of Mirawati, et al. (2019). Related to the knowledge of FP devices, there are two studies that specifically support these findings (Sari, et al. 2019; Canda, et al. 2018)

Research by Qurniyawati (2016) identified factors that significantly influence longterm contraception use, including the role of officers and the role of community leaders. The findings of this study are also consistent with those of Kumaladewi \& Pelupessy 
(2018). The latter found that support from husband, environmental factors, the role of health workers are significant factors in choosing implants by FP acceptors.

Better knowledge of contraceptive methods is not aligned with the number of contraceptive uses (Tilahun et al., 2013), a strategy is needed to improve understanding and knowledge. In addition, the presence of medical services can affect societal awareness in order to improve long-term contraception use Heard, et al. (2004). The best approach for reducing the prevalence rate of pregnancy is to encourage long-term contraceptive methods. It must be followed by counseling to raise awareness of the importance of delaying pregnancy, the side effects of contraceptives, and its substitution (Tilahun et al., 2013; Melka, et al. 2015). The existence of text messaging service may increase the knowledge of family planning (Johnson et al., 2017).

Based on these findings, it is important to study the profile and determinants of LAPM users in Jambi Province in the context of the formulation of appropriate policies to increase the use of LAPMs and decrease the birth rate. The objective of the study is to analyze as follows: 1) the determinants of LAPMs and non-LAPMs used by couples of reproductive age in Jambi Province; 2) the relationship between couples of reproductive age and use of LAPMs in Jambi Province.

\section{METHODS}

Main data used in this study are taken from raw data from the 2018 PMA of KKBPK (Performance Monitoring and Accountability of Population, Family Planning, and Family Development programs) in Jambi Province. The number of samples was 849 couples of reproductive age who used contraceptive methods / methods in Jambi Province.

Binary logit regression is used to analyze the determinants of the selection between LAPM and non-LAPM by couples of reproductive age as FP acceptors, using the following equation:

$$
\begin{aligned}
Y= & \beta_{0}+\beta_{1} X_{1}+\beta_{2 . D 1} X_{2 . D 1}+\beta_{2 . D 2} X_{2 . D 2}+\beta_{2 . D 3} X_{2 . D 3}+\beta_{3 . D 1} X_{3 . D 1}+\beta_{3 . D 2} X_{3 . D 2}+ \\
& \beta_{3 . D 3} X_{3 . D 3}+\beta_{4} X_{4}+\beta_{5} X_{5}+\beta_{6} X_{6}+\beta_{7} X_{7}+\beta_{8 . D 1} X_{8 . D 1}+\beta_{8 . D 2} X_{8 . D 2}+ \\
& \beta_{9} X_{9}+\beta_{10} X_{10}+\beta_{11} X_{11}+e_{i}
\end{aligned}
$$

where:

$\mathrm{Y}=$ probability of FP acceptors in couples of reproductive age choosing LAPM $(0=$ NonLAPM; 1 = LAPM)

$\mathrm{X} 1$ = woman's age (years), the base group category: $<=29$ years old, so that

X1.D1 $1=30-39 ; 0=$ others

X1.D2 $1=40+; 0=$ others

$\mathrm{X} 2$ = woman's educational attainment (the base group category: Primary School and below), so that:

X2.D1 $1=$ Junior High School; $0=$ others

X2.D2 $1=$ Senior High School; $0=$ others

X2.D3 $1=$ Higher Education; $0=$ others

$\mathrm{X} 3$ = partner's/husband's educational attainment (the base group category: Primary School and below), so that:

X3.D1 $1=$ Junior High School; $0=$ others

X3.D2 $1=$ Senior High School; $0=$ others

X3.D3 $1=$ Higher Education; $0=$ others

$\mathrm{X} 4=$ woman's employment status $(0=$ not employed, $1=$ employed $)$

$\mathrm{X} 5=$ ethnicity $(0=$ Jambi Malay, $1=$ non-Jambi Malay $)$

$\mathrm{X} 6=$ the actual number of surviving children (person)

$\mathrm{X} 7=$ the difference between the perceived ideal and actual number of surviving children 
(person)

$\mathrm{X} 8$ = the desire for more children (the base group category: want no more children) so

that:

X8.D1 $1=$ want more children; $0=$ others

X8.D2 $1=$ undecided; $0=$ others

$\mathrm{X} 9=$ scores of knowledge of contraceptive methods

$\mathrm{X} 10=$ economic conditions $(0=$ lower-middle, $1=$ upper-middle $)$

$\mathrm{X} 11=$ residence $(0=$ rural, $1=$ urban $)$

In the next stage, two approaches are used to examine the relationship between the characteristics of couples of reproductive age and the selection of one of the LAPMs. For continuous variables/characteristics (age, the actual number of surviving children, the difference between the ideal and actual number of surviving children, and knowledge of contraceptive methods), One-way ANOVA test (analysis of variance) was conducted. On the other hand, for categorical variables/characteristics (educational attainment, employment status, ethnicity, the desire for more children, wealth quintile, and urbanrural residence), Chi-square test was carried out.

\section{RESULTS AND DISCUSSION}

\section{Contraceptive use based on its method in Jambi Province}

Based on the methods of contraception, 5.42 percent of couples of reproductive age in Jambi Province use traditional methods (periodic abstinence, withdrawal, and other traditional methods), while 94.58 percent use modern methods.

Modern methods based on its period of effectiveness can be classified into two types: LAPMs (long-acting and permanent methods) and non-LAPMs. LAPMs are methods of contraception that can last three years to lifetime, including IUD, implants, FS, and MS. Non-LAPMs are methods other than LAPMs, including condoms, pills, injections, and others.

Of the total users of modern contraceptives, only 18.26 percent use LAPMs. Most of the others (76.33 percent) are non-LAPM users. Implants are the most commonly used long-acting and permanent method (LAPM) by FP acceptors. More than half (58.06 percent) of the users choose implant, followed by FS (23.87 percent) and IUD (18.06 percent). In addition, of non-LAPMs, the use of injections is prevalent. More than two thirds (66.82 percent) of non-LAPM users choose injections (for 1 and 3 months), followed by pills at 28.70 percent. The remaining small proportions are male condoms (4.17 percent) and Lactational Amenorrhea Method (LAM) (0.31 percent).

\section{Profile of active FP acceptors of LAPM users in Jambi Province}

The profile of LAPM users in Jambi Province was evaluated on the basis of user characteristics, including woman's age, educational attainment of couples of reproductive age (husband and wife), ethnicity, the actual number of surviving children, knowledge of contraceptive methods, economic conditions, place of service, and urban-rural residence. Age

Age affects directly and indirectly the behavior and patterns of individual decisionmaking. The influence of age can be attributed to experience and maturity that accompany the increase in a person's age. In the sense of family planning, the younger the woman of reproductive age use LAPM, the more effective the effort in declining the birth rate.

The age of women using LAPM is typically older than non-LAPM users. The average age of LAPM users is 36.47 years, while the average age of non-LAPM users is 34.56 years (Table 1 ). 
Table 1. Distribution of couples of reproductive age based on the woman's age and the contraceptive method in Jambi Province, 2018

\begin{tabular}{|c|c|c|c|c|c|}
\hline \multirow{2}{*}{ Age group } & \multicolumn{3}{|c|}{ LAPM } & \multirow{2}{*}{ Total LAPM } & \multirow{2}{*}{ Non-LAPM } \\
\hline & FS & Implants & IUD & & \\
\hline$=<29$ & 2.70 & 28.89 & 17.86 & 20.65 & 10.65 \\
\hline $30-34$ & 13.51 & 14.44 & 17.86 & 14.84 & 16.36 \\
\hline $35-39$ & 40.54 & 26.67 & 28.57 & 30.32 & 21.45 \\
\hline $40-44$ & 24.32 & 13.33 & 21.43 & 17.42 & 23.92 \\
\hline $45-49$ & 18.92 & 16.67 & 14.29 & 16.77 & 17.90 \\
\hline Total & 100.00 & 100.00 & 100.00 & 100.00 & 9.72 \\
\hline Average & 39.11 & 35.34 & 36.61 & 36.47 & 34.56 \\
\hline
\end{tabular}

Source: 2018 PMA (processed data)

Based on age distribution, the largest proportion of LAPM users is in the age group 35-39. Based on its type of LAPMs, the pattern is the same for FS and IUD. However, there is a small different in implants with the highest percentage in the age group 29 and under. In comparison, the average age of FS users is 39.11 years, followed by IUD users of 36.61 years, and implant users of 35.34 years.

\section{Educational attainment}

Education is one of the factors that affect one's decisions on various aspects of life (Yulmardi, Amir and Junaidi, 2020). In the context of family planning, the higher the individual's educational level is, the better the ability to make decisions on family planning.

Women of reproductive age who are also LAPM users have better education than non-LAPM users. As many as 39.20 percent of non-LAPM users have completed primary education or below, while just 27.74 percent for LAPM users. on the other hand, 30.32 percent and 14.19 percent of LAPM users have finished senior high school and higher education respectively. Conversely, for non-LAPM users, the percentage is just 25.15 percent for senior high school and 10.65 percent for higher education (Table 2).

Table 2. Distribution of couples of reproductive age based on the woman's educational attainment and the contraceptive method in Jambi Province, 2018

\begin{tabular}{|c|c|c|c|c|c|}
\hline \multirow{2}{*}{ Educational Attainment } & \multicolumn{3}{|c|}{ LAPM } & \multirow{2}{*}{$\begin{array}{r}\text { Total } \\
\text { LAPM }\end{array}$} & \multirow{2}{*}{$\begin{array}{r}\text { Non- } \\
\text { LAPM }\end{array}$} \\
\hline & FS & Implants & IUD & & \\
\hline$=<$ Primary School & 27.03 & 33.33 & 10.71 & 27.74 & 39.20 \\
\hline Junior High School & 18.92 & 32.22 & 25.00 & 27.74 & 25.00 \\
\hline Senior High School & 43.24 & 24.44 & 32.14 & 30.32 & 25.15 \\
\hline Higher Education & 10.81 & 10.00 & 32.14 & 14.19 & 10.65 \\
\hline Total & 100.00 & 100.00 & 100.00 & 100.00 & 100.00 \\
\hline
\end{tabular}

Source: 2018 PMA (processed data)

The distribution of the contraceptive method based on the husband's educational attainment is presented in detail in Table 3 .

Table 3. Distribution of couples of reproductive age based on the husband's educational attainment and the contraceptive method in Jambi Province, 2018

\begin{tabular}{|c|c|c|c|c|c|}
\hline \multirow{2}{*}{ Educational Attainment } & \multicolumn{3}{|c|}{ LAPM } & \multirow{2}{*}{$\begin{array}{r}\text { Total } \\
\text { LAPM }\end{array}$} & \multirow{2}{*}{$\begin{array}{l}\text { Non- } \\
\text { LAPM }\end{array}$} \\
\hline & FS & Implants & IUD & & \\
\hline$=<$ Primary School & 16.22 & 31.11 & 10.71 & 23.87 & 41.51 \\
\hline Junior High School & 21.62 & 32.22 & 14.29 & 26.45 & 22.84 \\
\hline Senior High School & 43.24 & 27.78 & 39.29 & 33.55 & 27.78 \\
\hline Higher Education & 18.92 & 8.89 & 35.71 & 16.13 & 7.87 \\
\hline Total & 100.00 & 100.00 & 100.00 & 100.00 & 100.00 \\
\hline
\end{tabular}

Source: 2018 PMA (processed data) 
Educational attainment of husband of couples in reproductive age who choose LAPM is also comparatively higher than that of non-LAPM users. Of the total non-LAPM users, 41.51 percent are husband in primary school or below group. On the other hand, LAPM users with husband in primary school or below group are only 23.87 percent. 33.55 percent and 16.13 percent of husband of couples using LAPM have completed senior high education and higher education, respectively. Conversely, only 27.78 percent and 7.87 percent of husband in non-LAPM group have completed senior high education and higher education, respectively.

\section{Actual number of surviving children}

The average actual number of surviving children of LAPM users is significantly higher than that of non-LAPM users. On average, LAPM users have 2.39 children, while non-LAPM users have 2.15 children (Table 4 ).

Table 4. Distribution of couples of reproductive age based on the actual number of surviving children and the contraceptive method in Jambi Province, 2018

\begin{tabular}{|c|c|c|c|c|c|}
\hline \multirow{2}{*}{$\begin{array}{l}\text { Number of } \\
\text { children }\end{array}$} & \multicolumn{3}{|c|}{ LAPM } & \multirow{2}{*}{$\begin{array}{r}\text { Total } \\
\text { LAPM }\end{array}$} & \multirow{2}{*}{$\begin{array}{l}\text { Non- } \\
\text { LAPM }\end{array}$} \\
\hline & FS & Implants & IUD & & \\
\hline 0 & 0.00 & 0.00 & 7.10 & 1.29 & 0.62 \\
\hline $1-2$ & 16.20 & 77.70 & 50.00 & 58.06 & 71.76 \\
\hline $3-4$ & 78.40 & 21.10 & 35.70 & 37.42 & 24.38 \\
\hline$>=5$ & 5.40 & 1.10 & 7.10 & 3.23 & 3.24 \\
\hline Total & 100.00 & 100.00 & 100.00 & 100.00 & 100.00 \\
\hline Average & 3.30 & 2.03 & 2.36 & 2.39 & 2.15 \\
\hline
\end{tabular}

Source: 2018 PMA (processed data)

Based on the methods of contraception, it can be stated that couples who choose FS have an average of 3.3 children, followed by IUD users with 2.36 children, and implant users with 2.03 children. The largest proportion (78.40 percent) is FS group with 3-4 children.

\section{Difference between the perceived ideal number (PIN) and the actual number (AN) of surviving children}

In general, it can be stated that the average PIN of children of LAPM users is 2.46 children which is relatively lower than that of non-LAPM users of 2.53 children. In contrast, the AN of surviving children of LAPM users is higher than that of non-LAPM users (Table 5).

Table 5. Distribution of couples of reproductive age based on pin and an of surviving children and the contraceptive method in Jambi Province, 2018

\begin{tabular}{|c|c|c|c|c|c|}
\hline \multirow{2}{*}{ Description } & \multicolumn{3}{|c|}{ LAPM } & \multirow{2}{*}{$\begin{array}{r}\text { Total } \\
\text { LAPM }\end{array}$} & \multirow{2}{*}{$\begin{array}{l}\text { Non- } \\
\text { LAPM }\end{array}$} \\
\hline & FS & Implants & IUD & & \\
\hline$\overline{\mathrm{PIN}}<\mathrm{AN}$ & 64.86 & 11.11 & 21.43 & 25.81 & 15.43 \\
\hline $\mathrm{PIN}=\mathrm{AN}$ & 29.73 & 53.33 & 39.29 & 45.16 & 45.37 \\
\hline $\mathrm{PIN}>\mathrm{AN}$ & 5.41 & 35.56 & 39.29 & 29.03 & 39.20 \\
\hline Total & 100.00 & 100.00 & 100.00 & 100.00 & 100.00 \\
\hline Average PIN & 2.62 & 2.36 & 2.61 & 2.46 & 2.53 \\
\hline Average AN & 3.30 & 2.03 & 2.36 & 2.39 & 2.15 \\
\hline Difference between PIM and AN & -1.32 & 0.33 & 0.25 & 0.07 & 0.38 \\
\hline
\end{tabular}

Source: 2018 PMA (processed data)

In terms of the difference between the PIN and AN, LAPM users have a smaller difference than non-LAPM users. In other words, the mean AN of surviving children of LAPM users is closer to the desired ideal number of children relative to non-LAPM users. Based on the type of LAPMs, couples in FS group have a lower desired ideal number 
relative to the mean number of surviving children. In other words, they have more children than their PIN.

Based on its type of LAPMs, couples in FS group have lower PIN compared to the mean AN of surviving children. In other words, they have more children than their desired ideal number. Based on its proportion, almost one-third (64.86 percent) of couples in FS group have more children than their PIN. In addition, IUD users and implant users have more PIN than their AN of surviving children.

\section{Desire for more children}

Almost three-quarters (72.90 percent) of LAPM users stated that they did not want more children. The remaining 17.42 percent said they wanted more children and 9.86 percent had not decided.

Compared to non-LAPM users, the proportion of LAPM users who do not wish to have more children is relatively higher. Among non-LAPM users, only about half (54.91 percent) of them did not want more children. Almost one-third (30.86 percent) wanted more children, and the rest (9.72 percent) had not decided (Table 6).

Table 6. Distribution of couples of reproductive age based on the desire for more children and the contraceptive method in Jambi Province, 2018

\begin{tabular}{|c|c|c|c|c|c|}
\hline \multirow{2}{*}{ Description } & \multicolumn{3}{|c|}{ LAPM } & \multirow{2}{*}{$\begin{array}{r}\text { Total } \\
\text { LAPM }\end{array}$} & \multirow{2}{*}{$\begin{array}{l}\text { Non- } \\
\text { LAPM }\end{array}$} \\
\hline & FS & Implants & IUD & & \\
\hline Want no more children & 94.59 & 66.67 & 64.29 & 72.90 & 54.91 \\
\hline Want more children & 0.00 & 22.22 & 25.00 & 17.42 & 30.86 \\
\hline Undecided & 5.41 & 11.11 & 10.71 & 9.68 & 9.72 \\
\hline Total & 100.00 & 100.00 & 100.00 & 100.00 & 100.00 \\
\hline
\end{tabular}

Source: 2018 PMA (processed data)

Based on the type of LAPMs, there is a common pattern between implants and IUD users on the desire for more children. About a third of implant users and IUD users said they wanted no more children. Moreover, especially due to its permanent nature, FS users are expected to have no desire for more children. However, the data reveals that there are still 5.41 percent who are either in doubt or have not yet decided whether or not they want to have additional children.

\section{Knowledge of methods of contraception}

In general, it can be argued that users of LAPMs have a better knowledge of contraceptive methods than non-LAPM users. The average score of knowledge (in contraceptive methods) in the LAPM user group is 8.39 (knowing 8-9 out of 15 methods), while the non-LAPM user group score is 7.58 (knowing 7-8 out of 15 methods).

Table 7. Distribution of couples of reproductive age based on the knowledge of contraceptive methods and the contraceptive method in Jambi Province, 2018

\begin{tabular}{|c|c|c|c|c|c|}
\hline \multirow{2}{*}{ Score } & \multicolumn{3}{|c|}{ LAPM } & \multirow{2}{*}{$\begin{array}{r}\text { Total } \\
\text { LAPM }\end{array}$} & \multirow{2}{*}{$\begin{array}{l}\text { Non- } \\
\text { LAPM }\end{array}$} \\
\hline & FS & Implants & IUD & & \\
\hline $0-5$ & 8.11 & 15.56 & 0.00 & 10.97 & 18.67 \\
\hline $6-10$ & 70.27 & 73.33 & 89.29 & 75.48 & 71.30 \\
\hline $11-15$ & 21.62 & 11.11 & 10.71 & 13.55 & 10.03 \\
\hline Total & 100.00 & 100.00 & 100.00 & 100.00 & 100.00 \\
\hline Average score & 8.92 & 8.03 & 8.82 & 8.39 & 7.58 \\
\hline
\end{tabular}

Source: 2018 PMA (processed data)

Based on its type of LAPMs, FS users have the highest knowledge score of 8.92. IUD users are in the second place with a score of 8.83 and followed by implant users of 8.03 . 


\section{Economic conditions}

In general, it can be stated that LAPM users have better economic condition than non-LAPM users. Nearly half (47.74 percent) of LAPM users are in the upper middle and the highest wealth quintile, and just around one third (31.61 percent) are in the lower middle and the lowest wealth quintile. on the other hand, almost half (47.99 percent) of non-LAPM users are in the middle lower and lowest economic conditions (Table 8).

Table 8. Distribution of couples of reproductive age based on the economic conditions and the contraceptive method in Jambi Province, 2018

\begin{tabular}{lrrrrr}
\hline \multirow{2}{*}{ Wealth Quintile } & \multicolumn{3}{c}{ LAPM } & & Total \\
& FS & Implants & IUD & LAPM & Non- \\
& 13.51 & 18.89 & 3.57 & 14.84 & 25.93 \\
\hline Lowest & 21.62 & 17.78 & 7.14 & 16.77 & 22.07 \\
Lower-middle & 13.51 & 22.22 & 25.00 & 20.65 & 18.52 \\
Middle & 18.92 & 27.78 & 25.00 & 25.16 & 20.22 \\
Upper-middle & 32.43 & 13.33 & 39.29 & 22.58 & 13.27 \\
Highest & 100.00 & 100.00 & 100.00 & 100.00 & 100.00 \\
\hline Total & & & & &
\end{tabular}

Source: 2018 PMA (processed data)

Based on its type of LAPMs, the economic conditions of FS and implant users do not present a clear pattern. In other words, they are fairly distributed in economic conditions. However, IUD users are dominated by couples with better economic conditions. About two-thirds (64.29 percent) of IUD users are in the upper middle and the highest wealth quintile, and only 10.71 percent are in the lower middle and the lowest wealth quintile.

\section{Urban-rural residence}

Based on residence, both the proportion of LAPM users and non-LAPM users in rural areas is greater than urban areas (Table 9). This is due to more rural areas (as well as population) than urban areas in Jambi Province. In 2018, there were 1,399 rural administrative areas and there were only 163 urban administrative areas in Jambi Province

Table 9. Distribution of couples of reproductive age based on the urban-rural residence and the contraceptive method in Jambi Province, 2018

\begin{tabular}{lrrrrr}
\hline \multirow{2}{*}{ Residence } & \multicolumn{3}{c}{ LAPM } & Total & $\begin{array}{r}\text { Non- } \\
\end{array}$ \\
\cline { 2 - 4 } & FS & Implants & IUD & LAPM & LAPM \\
\hline Urban & 27.03 & 15.56 & 50.00 & 24.52 & 28.09 \\
Rural & 72.97 & 84.44 & 50.00 & 75.48 & 71.91 \\
\hline Total & 100.00 & 100.00 & 100.00 & 100.00 & 100.00 \\
\hline
\end{tabular}

Source: 2018 PMA (processed data)

Based on the proportion of each type of LAPM, it can be stated that the largest proportion of LAPM used in urban areas is IUD, followed by FS, and implants. In comparison, the most commonly used LAPMs in rural areas are implants, followed by FS, and IUD.

\section{Model of LAPM and non-LAPM selection on active FP acceptors in Jambi Province}

Overall model fit test of the model includes three approaches: Omnibus Test of Model Coefficients, Hosmer and Lemeshow, and Classificiation Table 2 x 2. Based on the Omnibust Test of Model Coefficients, the statistical value of Chi square was estimated at 67.682 with a p-value of 0.000 . Therefore, it can be inferred that the independent variables in the model concurrently affect the decisions and behaviors of active FP acceptors in the selection of contraceptive methods between LAPMs and non- 
LAPMs. Based on the Hosmer and Lemeshow test, the Chi-square value was 7.507 with a p-value of 0.483 . Because the Chi_square is not significant ( $p>0.05$ ), it can be concluded that the predicted probability is consistent with the observed probability. In other words, there is no difference between the model and the data so the model is fit.

Table 10. Omnibus Test of model coefficients and Hosmer and Lemeshow for the model of LAPMS and Non-LAPMS selection

\begin{tabular}{lccc}
\hline & Chi-square & df & Sig. \\
\hline Omnibus Test of Model Coefficients & 67.682 & 16 & 000 \\
Hosmer and Lemeshow Test & 7.506 & 8 & .483 \\
\hline
\end{tabular}

Source: 2018 PMA (processed data)

Classification table $2 \times 2$ (Table 11) shows how well the model groups cases into two categories (active FP acceptors using LAPM and non-LAPM). The overall accuracy of the prediction is 80.7 percent, while that of active non-LAPM acceptors is 98.6 percent and that of LAPM acceptors is 5.8 percent. In other words, the accuracy of the model in estimating the probability of active non-LAPM acceptors is relatively greater than the LAPM acceptors.

Table 11. Classification 2 X 2 for the model of LAPMS and Non-LAPMS selection

\begin{tabular}{lcccc}
\hline \multirow{2}{*}{ Observation } & \multicolumn{2}{c}{ Predicting category } & & $\begin{array}{r}\text { Accuracy of } \\
\text { prediction }\end{array}$ \\
\cline { 2 - 4 } Category & Non-LAPM & LAPM & \\
& Non-LAPM & 639 & 9 & 98.6 \\
& LAPM & 146 & 9 & 5.8 \\
\hline Total & & & 80.7 \\
\hline Source: 2018 PMA (processed data) & & &
\end{tabular}

The estimation of the coefficients and the partial hypothesis testing of the model are shown in Table 12. In terms of age, it can be stated that woman's age does not have a significant effect on the choice between LAPM and non-LAPM. In other words, there is no difference in the selection between LAPM and non-LAPM based on their age. This finding is not in line with some previous studies (Widyastuti, \& Mahmudah, 2012; Budiarti, et al. 2017; Rizani, 2019; Dewi \& Notobroto, 2014; Mirawati, et al. 2019).

There is no difference in the chances of LAPM or non-LAPM selection based on the educational attainment. This is demonstrated by the insignificant coefficients (X2.D1, $\mathrm{X} 2 \mathrm{D} 2$, and X2D3) of the model. This finding is not in line with some previous studies (Duze \& Mohammed, 2006; Sudiarti \& Kurniawidjaya, 2013). But this finding is supported by research Fitrianingsih \& Melaniani (2016)

However, husband's educational attainment has a significant influence on the preference. Based on the odds ratio, woman with husband who have finished junior high school education (X3.D1) have a 2.110 times (higher) chance of choosing LAPM relative to woman with husband in primary or lower education (base category). Woman with husband in senior high school group (X3.D2) and in higher education group (X3.D3) have a 2.077 times and a 3.219 times (higher) probability of preferring LAPM relative to woman with husband graduating from primary school and lower level education.

Furthermore, in terms of the employment status of the woman (X4), employed women tend to choose LAPM relative to unemployed woman. By having a significant positive coefficient and taking into account the odds ratio, working woman is 1.656 times (higher) likely to choose LAPM relative to unemployed woman. This result is in line with previous studies (Budiarti, et al. 2017; Sudiarti \& Kurniawidjaya, 2013; Aryati, et al. 2019) 
Ethnicity (X5) has no significant effect on the selection between LAPMs and nonLAPMs. In other words, there is no significant difference between Jambi Malays and other ethnic groups in Indonesia in the preference of LAPM and non-LAPM.

The number of surviving children (X6) does not significantly influence the selection between LAPM and non-LAPM. This finding is not in line with some previous studies (Duze \& Mohammed, 2006; Widyastuti \& Mahmudah, 2012; Sudiarti \& Kurniawidjaya, 2013; Dewi \& Notobroto, 2014).

However, the difference between the perceived ideal and actual number of surviving children (X7) shows a significant effect. Based on the odds ratio of 0.602 (smaller than 1), couples of reproductive age with greater positive difference value (the perceived ideal number is less than the number of surviving children) are less likely to prefer a long-acting and permanent method of contraception (LAPM).

Desire for more children (X8.D1) has a significant negative effect on the selection between LAPM and non-LAPM. This finding is also supported by several previous studies (Fitrianingsih \& Melaniani, 2016)

The odds ratio of 0.602 indicates that couples who want another children have a 0.602 times (lower) chance of choosing LAPM relative to those that do not want another children (base category). It can be seen from the insignificance of the coefficient of X8.D2.

Table 12. Estimation of the model of LAPM and Non-LAPM selection

\begin{tabular}{|c|c|c|c|c|c|c|}
\hline Variable & Coef. & S.E. & Wald & $\mathrm{df}$ & Sig. & Odds Ratio \\
\hline $\mathrm{X} 1$ & -.050 & .165 & .093 & 1 & .760 & .951 \\
\hline $\mathrm{X} 2$ & & & 1.219 & 3 & .748 & \\
\hline $\mathrm{X} 2 . \mathrm{D} 1$ & .207 & .268 & .597 & 1 & .440 & 1.230 \\
\hline $\mathrm{X} 2 . \mathrm{D} 2$ & .222 & .316 & .494 & 1 & .482 & 1.249 \\
\hline $\mathrm{X} 2 . \mathrm{D} 3$ & -.034 & .419 & .006 & 1 & .936 & .967 \\
\hline $\mathrm{X} 3$ & & & 11.326 & 3 & .010 & \\
\hline X3.D1 & .747 & .271 & 7.577 & 1 & .006 & 2.110 \\
\hline X3.D2 & .731 & .295 & 6.120 & 1 & .013 & 2.077 \\
\hline X3.D3 & 1.169 & .400 & 8.522 & 1 & .004 & 3.219 \\
\hline $\mathrm{X} 4$ & .504 & .225 & 5.021 & 1 & .025 & 1.656 \\
\hline $\mathrm{X} 5$ & -.079 & .194 & .167 & 1 & .683 & .924 \\
\hline X6 & .019 & .142 & .019 & 1 & .891 & 1.020 \\
\hline X7 & -.275 & .128 & 4.632 & 1 & .031 & .760 \\
\hline X8 & & & 3.211 & 2 & .201 & \\
\hline X8.D1 & -.507 & .305 & 2.760 & 1 & .097 & .602 \\
\hline X8.D2 & .053 & .333 & .026 & 1 & .873 & 1.055 \\
\hline X9 & .123 & .048 & 6.603 & 1 & .010 & 1.131 \\
\hline X10 & .363 & .222 & 2.684 & 1 & .100 & 1.438 \\
\hline X11 & -.854 & .243 & 12.322 & 1 & .000 & .426 \\
\hline Constant & -2.931 & .606 & 23.418 & 1 & .000 & .053 \\
\hline
\end{tabular}

Source: 2018 PMA (processed data)

While woman's educational attainment does not have a significant impact, woman's knowledge of contraceptive methods (X9) clearly shows a significant and positive effect. Woman who knows more contraceptive methods are more likely to choose LAPM. Looking at the odds ratio, it can be stated that learning one more method would increase the chance of 1.131 times (higher) preferring LAPM. The same result is also found in previous studies including (Duze \& Mohammed, 2006; Widyastuti \& Mahmudah, 2012; Sudiarti \& Kurniawidjaya, 2013; Dewi \& Notobroto, 2014; Sari, et al. 2019; Canda, et al. 2018). 
Economic condition (X10) has a significant effect. Based on its odds ratio, couples of reproductive age in middle to upper class have a 1.438 times (higher) probability of preferring LAPM relative to the middle to lower class (base category). This finding is also supported by several previous studies (Duze \& Mohammed, 2006; Widyastuti \& Mahmudah, 2012).

Furthermore, in terms of residence, there is a true difference in the selection between LAPM and non-LAPM by couples of reproductive age in urban and rural areas. The odds ratio of 0.426 shows that the probability of urban couples is 0.426 times (lower) to choose LAPM relative to rural couples (base category). Place of residence related to environmental factors. The influence of environmental factors on the selection between LAPM and non-LAPM is supported by previous research (Kumaladewi \& Pelupessy, 2018).

\section{Relationship between the characteristics of couples of reproductive age and the selection of the type of LAPMs in Jambi Province}

Analysis of the relationship between the characteristics of the couples and the preferences of contraceptives used two different approaches. One Way ANOVA (analysis of variance) was used to evaluate continuous variables/characteristics (age, the number of surviving children, the difference between the ideal and actual number of surviving children, and knowledge of contraceptive methods). Meanwhile Chi-square test was used to analyze categorical variables/characteristics (educational attainment, employment status, ethnicity, the desire for more children, wealth quintile, and urban-rural residence). A summary of the test is given in Table 12, and the detailed output of the calculation is attached.

Table 13. Characteristics of couples in reproductive age and the selection of LAPMS

\begin{tabular}{llrr}
\hline Characteristics & Analysis Method & Chi-Square/ F & Sig. \\
\hline Age & ANOVA & 3.791 & 0.025 \\
Woman's educational attainment & Chi-Square Test & 16.575 & 0.011 \\
Husband's educational attainment & Chi-Square Test & 19.908 & 0.003 \\
Woman's employment status & Chi-Square Test & 4.271 & 0.118 \\
Woman's ethnicity & Chi-Square Test & 1.738 & 0.419 \\
Number of surviving children & ANOVA & 24.318 & 0.000 \\
Difference between the PIN \& AN of children & ANOVA & 18.550 & 0.000 \\
Desire for more children & Chi-Square Test & 12.634 & 0.013 \\
Knowledge of contraceptive methods & ANOVA & 2.950 & 0.055 \\
Wealth quintile & Chi-Square Test & 6.932 & 0.031 \\
Urban-rural residence & Chi-Square Test & 13.857 & 0.001 \\
\hline Source: 2018 PMA (processed data) & & &
\end{tabular}

Based on Table 13, woman's age has a significant relationship to the selection of type of LAPMs. Table 1 confirms statistically that older woman has a higher tendency to choose FS, followed by IUD and implants.

The education of the wife and husband has a significant relationship with the choice of LAPM type. Referring to Table 2 and Table 3 in the previous section, it is statistically confirmed that couples of reproductive age (wife and husband) with higher educational level tend to use IUD, followed by FS and implants.

As for the woman's employment status, while it affects the selection between LAPM and non-LAPM (Table 12), it does not influence on the selection of method between LAPMs. In other words, there is no significant difference between working woman and unemployed woman in the use of FS, IUD, or implants.

There is also no significant relationship between woman's ethnicity and the 
selection of LAPM type. In other words, besides its insignificant influence on the choice between LAPM and non-LAPM, ethnicity is not correlated either with the type of LAPMs (FS, implants, and IUD).

The number of surviving children is relation to the selection of one LAPM type. Referring to Table 4 in the previous section, it is statistically confirmed that couples with more children tend to choose FS, followed by IU, and implants. In line with this fact, the difference between the perceived ideal and actual number of surviving children and the desire for more children also have significant relationships with the selection between FS, implants, and IUD.

Table 12 indicates that the selection between FS, implants, and IUD is also closely related to the economic conditions of couples. Referring to Table 8 in the previous section, the significant Chi-square probability of the variable has been statistically confirmed that IUD users tend to come from couples with better economic conditions than FS and implant users.

Knowledge of contraceptive methods also reveals a strong relationship to the preference of FS, implants, and IUD. This finding reinforces the trend seen in Table 7, which indicates that FS users have a better knowledge of contraceptive methods than IUD and implant users.

Based on urban-rural residence, there are variations in patterns in the use of LAPM devices between urban couples and rural couples. The significant Chi-square probability for the variable has statistically confirmed that the largest proportion in LAPM use in urban area is IUD, followed by FS, and implants. On the other hand, the largest use of LAPM type in rural area is implants, followed by FS, and IUD.

\section{CONCLUSIONS AND RECOMMENDATIONS}

\section{Conclusions}

Based on the methods of contraception, 5.42 percent of couples of reproductive age in Jambi Province use traditional methods, while 94.58 percent use modern methods. Of the total users of modern methods, only 18.26 percent use long-acting and permanent methods of contraception. Most of the others (76.33 percent) are non-LAPM users. The most commonly used LAPM by FP acceptors is implants, followed by FS, and IUD. By comparing the characteristics of LAPM users and non-LAPM users, it can be inferred that LAPM users in Jambi Province are distinguished by comparatively older age, better educational level, more children, most of whom do not want more children, better knowledge of contraceptive methods, and better economic conditions. In addition, the proportion of urban couples of reproductive age using LAPMs tends to be smaller than non-LAPM users. By contrast, rural couples using LAPMs tend to be larger in number than non-LAPM users.

Factors that have a significant impact on the selection between LAPMs and nonLAPMs by couples of reproductive age in Jambi Province are husband's educational attainment, woman's employment status, the difference between the ideal and actual number of surviving children, the desire for more children, knowledge of contraceptive methods, economic conditions, and urban-rural residence. Characteristics of reproductive age couples that are significantly related to the selection of contraceptive devices (of modern methods) (FS, implants, and IUD) are woman's age, woman's educational attainment, the number of surviving children, the difference between the ideal and actual number of surviving children, the desire for more children, knowledge of contraceptive methods, economic conditions, and urban-rural residence. 


\section{Recommendations}

In order to boost the effectiveness of contraceptive methods in the reduction of birth rates, the government, in this case BKKBN as the main stakeholder, should further increase the proportion of the use of LAPM. Policies or efforts to directly improve the use of LAPMs are proposed as follows: 1) increasing the number of FS and IUD socialization due to the low proportion of the use of these two methods; 2 ) increasing the number of LAPM socialization for young couples of reproductive age (34 years and under) due to the low proportion of LAPM use of this age group; 3 ) the education of the husband has a significant impact on the couples' preference in LAPMs. The socialization about the importance of family planning, contraceptive methods, and reproductive health must therefore be increased for husbands. In addition, woman's knowledge of contraceptive methods also needs to be improved as it is also a significant factor in LAPM choices; 4) the average ideal number of children in LAPM users is not as expected (above 2.0). This is one of the factors that prevents women from using LAPMs. There is therefore a great need to strengthen the socialization of the slogan 'two children are better' in Jambi Province.

\section{ACKNOWLEDGEMENTS}

We would like to thank the Jambi Province BKKBN representative for providing funding this research

\section{REFERENCES}

Aldriana, N. (2013). Faktor-faktor yang berhubungan dengan penggunaan alat kontrasepsi dalam rahim (AKDR) di wilayah kerja Puskesmas Rokan Hulu Tahun 2013, Jurnal Maternity and Neonatal, 1(3), 111 - 122

Aryati, S., Sukamdi, S. \& Wiyastuti, D. (2019). Faktor-Faktor Yang Mempengaruhi Pemilihan Metode Kontrasepsi (Kasus Di Kecamatan Seberang Ulu I Kota Palembang), Majalah Geografi Indonesia, 33(1), 79 - 85

Benagiano, G. Bastianelli, C., \& Farris, M. (2007). Contraception: A social revolution, European Journal of Contraception and Reproductive Health Care, 12(1), 3-12, 2007, doi: 10.1080/13625180601012311

Budiarti, I., Nuryani, D.D. \& Hidayat, R. (2017). Determinan Penggunaan Metode Kontrasepsi Jangka Panjang (MKJP) pada Akseptor KB, Jurnal Kesehatan, 8(2), $220-224$

Canda, D., Sakung, J., \& Yusuf, H. (2018). Hubungan Pengetahuan dan Dukungan Suami dengan Pemilihan Metode Kontrasepsi Jangka Panjang Di Kelurahan Lolu Selatan Wilayah Kerja Puskesmas Birobuli, Jurnal Kolaboratif Sains, 1(1), 76-86

Cleland, J., Conde-Agudelo, A. Peterson, H., Ross, J., \& Tsui, A., Contraception and health, Lancet, 380(9837), 149-156. doi: 10.1016/S0140-6736(12)60609-6

Darney, B.G., Sosa-Rubi, S.G., Servan-Mori, E., Rodriguez, M.I., Walker, D., \& Lozano, R. (2016). The relationship of age and place of delivery with postpartum contraception prior to discharge in Mexico: A retrospective cohort study, Contraception, 93(6), 478-484. doi: 10.1016/j.contraception.2016.01.015

Dewi, P.H.C. \& Notobroto, H.B. (2014). Rendahnya Keikutsertaan Pengguna Metode Kontrasepsi Jangka Panjang Pada Pasangan Usia Subur, Jurnal Biometrika Kependudukan, 3(1), $66-72$

Duze, M.C., \& Mohammed, I.Z. (2006). Male knowledge, attitudes, and family planning practices in northern Nigeria," Afr J Reprod Health, 10(3),.53-65

Espey, E., \& Ogburn, T. (2011). Long-acting reversible contraceptives: Intrauterine devices and the contraceptive implant, Obstetrics and Gynecology, 117(3), 705- 
719. doi: 10.1097/AOG.0b013e31820ce2f0

Fitrianingsih, A.D.R. \& Melaniani, S. (2016). Faktor Sosiodemografi yang Memengaruhi Pemilihan Metode Kontrasepsi, Jurnal Biometrika dan Kependudukan, 5(10), 10 18

Glasier, A. \& Gebbie, A. (2016). Family Planning/ Contraception, International Encyclopedia of Public Health, 3(20), 92-101. doi: 10.1016/B978-0-12-8036785.00155-7

Goldsmith, K.A., Kasehagen, L.J., Rosenberg, K.D., Sandoval, A.P. \& Lapidus, J.A. (2008). Unintended childbearing and knowledge of emergency contraception in a population-based survey of postpartum women, Maternal and Child Health Journal, 12, 332-341. doi: 10.1007/s10995-007-0252-x

Hardiani, H. \& Junaidi, J. (2018). Determinants of Early Marriage And Model of Maturing Marriage Age Policy: A Case In Jambi Province, Indonesia. Innovative Issues and Approaches in Social Sciences, 11(1), 73 - 92

Hartanto, H. (2004). Keluarga Berencana dan Kontrasepsi, Jakarta: Pustaka Sinar Harapan

Heard, N.J., Larsen, U. \& Hozumi, D. (2004). Investigating access to reproductive health services using GIS: proximity to services and the use of modern contraceptives in Malawi, African Journal of Reproductive Health, 8(2), 164-179, https://doi.org/ $10.2307 / 3583189$

Herlinawati, H., Fitria, M. \& Santosa, H. (2013). Faktor-Faktor Yang Berhubungan Dengan Pemakaian Kontrasepsi Tubektomi Pada Wanita Pasangan Usia Subur Di RSUD Dr Pirngadi Medan Tahun 2012, Gizi, Kesehatan Reproduksi dan Epidemiologi, 2(3), 1 - 10

Johnson, D., Juras, R. Riley, P. Chatterji, M., Sloane, P., Choi, S.K., \& Johns, B. (2017). A randomized controlled trial of the impact of a family planning Health service on knowledge and use of contraception, Contraception, 95(1), 90-97, doi: 10.1016/j.contraception.2016.07.009

Kumaladewi, F., \& Pelupessy, R.A. (2018). Determinan Pengambilan Keputusan Menjadi Akseptor Kontrasepsi Implan, Jurnal Ilmiah Kebidanan (JIKI), 8(4), 182 - 190

Mehra, D., Agardh, A., Petterson, K.O., \& Östergren, P.O. (2012). Non-use of contraception: determinants among Ugandan university students, Global Health Action, 5(1). doi: 10.3402/gha.v5i0.18599

Melka, A.S., Tekelab, T. \& Wirtu, D. (2015). Determinants of long acting and permanent contraceptive methods utilization among married women of reproductive age groups in western Ethiopia: A cross-sectional study, Pan African Medical Journal, 21(246), 1-10, doi: 10.11604/pamj.2015.21.246.5835

Mirawati, R., Nuriaty, S., \& Wulandatika, D. (2019). Analisis Determinan Yang Berhubungan Dengan Pemilihanalat Kontrasepsi Oleh Akseptor KB Di PMB Tuti Gambut Kabupaten Banjar Kalimantan Selatan Tahun 2018, Journal of Midwifery and Reproduction, 2(1), 31-35

BKKBN, BPS, Kemenkes \& ICF. (2018). Indonesia Demographic and Health Survey 2017, Jakarta: BKKBN, BPS, Kemenkes, and ICF

Ningrum, S.S., Indarto, D. \& Wijaya, M. (2017). Determinan Yang Mempengaruhi Penggunaan Metode Kontrasepsi Jangka Panjang Di Kabupaten Sukoharjo, EProsiding Seminar Nasional Kebidanan Universitas Ngudi Waluyo

Notoatmodjo, S. (2014). Ilmu Perilaku Kesehatan, Jakarta: Rineka Cipta

Peipert, J.F., Madden, T., Allsworth, J.E., \& Secura, G.M. (2012). Preventing unintended pregnancies by providing no-cost contraception, Obstetrics and Gynecology, 
120(6), 1291-1297. doi:10.1097/AOG.0b013e318273eb56

Qurniyawati, E. (2016). Faktor Determinan Pemakaian Metode Kontrasepsi Jangka Panjang (MKJP), Warta Bhakti Husada Mulia, 3(1), 1 - 6

Rizani, R.P. (2019). Determinan Pemilihan Metode Kontrasepsi Jangka Panjang Oleh Wanita Usia Subur Di Desa Beusi Kabupaten Majalengka Tahun 2014, Jurnal Kesehatan Bidkesmas Respati, 1(10), 43 - 48

Sari, Y.N.I., Abidin, U.W., \& Ningsih, S. (2019). Faktor - Faktor Yang Berhubungan Dengan Minat Ibu Dalam Pemilihan Alat Kontrasepsi IUD, Jurnal Kesehatan Masyarakat, 5(1), 47 - 59

Secura, G.M., Allsworth, J.E., Madden, T., Mullersman, J.L., \& Peipert, J.F. (2010). The Contraceptive CHOICE Project: Reducing barriers to long-acting reversible contraception, American Journal of Obstetrics and Gynecology, 203(2): 115.e1115.e7. doi: 10.1016/j.ajog.2010.04.017

Septalia, R. \& Puspitasari, N. (2016). Faktor yang Memengaruhi Pemilihan Metode Kontrasepsi, Jurnal Biometrika dan Kependudukan, 5(2), 91-98. doi: 10.20473/jbk.v5i2.2016.91-98

Sudiarti, E.M. \& Kurniawidjaya, L. (2013). Faktor-Faktor Yang Berhubungan Dengan Rendahnya Pemakaian Metoda Kontrasepsi Jangka Panjang (MKJP) Pada Pasangan Usia Subur (Pus) Di Puskesmas Jagasatru Kota Cirebon Tahun 2012, Thesis, Fakultas Kesehatan Masyarakat, Depok: Universitas Indonesia, available at: http://lib.ui.ac.id/naskahringkas/2015-08/

Tilahun, T., Coene, G., Luchters, S., Kassahun, W., Leye, E., Temmerman, M. \& Degomme, O. (2013). Family Planning Knowledge. Attitude and Practice among Married Couples in Jimma Zone, Ethiopia, PLoS ONE, 8(4), 1-8. doi: 10.1371/journal.pone.0061335

Tsui, A.O., McDonald-Mosley, R., \& Burke, A.E. (2010). Family planning and the burden of unintended pregnancies, Epidemiologic Reviews, 32, 152-174. doi: 10.1093/epirev/mxq012

Yulmardi, Y., Amir, A., \& Junaidi, J. (2020). Household Livelihoods Strategies of Descendants of Transmigrant in Jambi Province, Indonesia, International Journal of Advanced Science and Technology, 29(3), 6118 - 6133

Widyastuti, A.H., \& Mahmudah, M. (2012). Faktor-faktor yang mempengaruhi pemilihan kontrasepsi suntik depo medroksi progesteron asetat di BPS Yacinta Plumbon Tawangmangu, Maternal, 7(7)

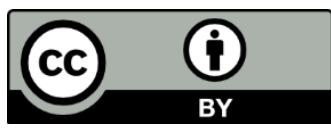

(C) 2020 by the authors. Licensee JPPD, Indonesia. This article is an open-access article distributed under the terms and conditions of the Creative Commons Attribution (CC BY) license (http://creativecommons.org/licenses/by/4.0/). 